\title{
Effects of growth hormone on glucose metabolism and insulin resistance in human
}

\author{
Shin-Hye Kim, MD, PhD, \\ Mi-Jung Park, MD, PhD
}

Department of Pediatrics, Inje University Sanggye Paik Hospital, Seoul, Korea
Received: 31 August, 2017

Accepted: 11 September, 2017

Address for correspondence:

Mi-Jung Park, MD, PhD

Department of Pediatrics, Inje University Sanggye Paik Hospital, 1342 Dongilro, Nowon-gu, Seoul 01767, Korea

Tel: +82-2-950-8826

Fax: +82-2-950-1246

E-mail:PMJ@paik.ac.kr

https://orcid.org/0000-0002-7202$500 x$
Growth hormone $(\mathrm{GH})$ is important for promotion of somatic growth and the regulation of substrate metabolism. Metabolic action of GH occurs in multiple tissues including the liver, muscle, fat and pancreas either directly or indirectly through insulin-like growth factor 1 . The diabetogenic action of $\mathrm{GH}$ has been well-described in previous in vivo studies. In this paper, we review the metabolic effects of GH on peripheral tissues focusing on glucose metabolism and insulin resistance, and discuss results from human studies on the long-term effects of $\mathrm{GH}$ administration on insulin resistance and hyperglycemia.

Keywords: Growth hormone, Glucose, Metabolism, Insulin resistance

\section{Introduction}

Glucose balance in circulation is tightly maintained within normal range by dynamic regulation of both glucose production (from liver and kidney) and glucose usage by peripheral tissues including the liver, muscle, fat, and kidney ${ }^{1)}$. Insulin, the primary regulator of glucose balance, lowers postprandial plasma glucose by increasing glucose uptake and usage from peripheral tissues and decreasing gluconeogenesis (synthesis of glucose from noncarbohydrate precursors such as lactate and alanine) and glycogenolysis (breakdown of glycogen to glucose). In contrast, counterregulatory hormones against insulin action, such as glucagon and epinephrine, prevent hypoglycemia by increasing gluconeogenesis and glycogenolysis and decreasing glucose uptake and consumption from peripheral tissues during fasting. Growth hormone $(\mathrm{GH})$ has been established as one of the counterregulatory hormones, ever since Houssay et al. had found that hypersensitivity to hypoglycemic effect of insulin was increased in hypophysectomized animals and insulin sensitivity was reduced after administration of anterior-pituitary extracts ${ }^{2}$. The diabetogenic effect of GH was also supported by the high prevalence of diabetes in acromegaly patients ${ }^{1)}$. The effects of GH on systemic glycemic control is complex partly due to its indirect effects via insulin-like growth factor 1 (IGF-1), which has glucose-lowering effects similar to insulin. For instance, adults with GH deficiency are paradoxically associated with abdominal obesity and insulin resistance, which may be partly associated with their reduced IGF-1 action. This review will summarize the direct and indirect effects of GH on glucose metabolism in peripheral tissues at the molecular level, and also discuss results from human studies investigating the effect of $\mathrm{GH}$ administration on glycemic control and insulin resistance.

\section{Effects of GH on glucose metabolism}

Studies investigating the effects of GH on glucose metabolism have demonstrated that GH increases glucose production through gluconeogenesis and glycogenolysis from the liver and kidney. Patients with acromegaly and human individuals exposed to high doses of GH showed markedly increased gluconeogenesis activity in the liver and kidney ${ }^{3)}$. Additionally, 
a recent in vivo study demonstrated that GH treatment increased the mRNA expression of 2 major gluconeogenic genes, phosphoenolpyruvate carboxy-kinase and glucose6-phosphatase, in mouse hepatocytes ${ }^{4)}$. GH administration was found to increase glycogenolysis in healthy adults, and inversely, pituitary microsurgery in patients with acromegaly decreased glycogenolysis ${ }^{5}$. Despite the increased glycogenolysis, significantly increased hepatic glycogen contents were reported in transgenic rats overexpressing the human $G H$ gene, suggesting increased glycogen synthesis by excessive $\mathrm{GH}^{6)}$. Enhanced glycogen synthase activity was also reported in those human $G H$ transgenic rats ${ }^{6}$.

Previous studies have shown that GH suppresses glucose uptake in the adipose tissue. An in vivo study demonstrated that $\mathrm{GH}$ administration in rats suppresses the amount of glucose transporter 1 (GLUT1) and GLUT4 in adipocyte plasma membrane ${ }^{7}$. Recently, the molecular mechanism of the inhibitory effect of GH on GLUT translocation has been revealed. The insulin-dependent cellular response, which includes trafficking of GLUT4 to the plasma membrane, requires the activation of phosphoinositide 3-kinase (PI3K), a key mediator of metabolic signaling downstream of the insulin receptor. PI3K signaling is negatively regulated by the $\mathrm{p} 85$ regulatory subunit. GH was found to induce up-regulation of p85 in white adipose tissues in mice with excess GH production, and in adipocytes treated with GH in an in vitro study ${ }^{8)}$. These results imply a mechanism involving $\mathrm{GH}$-induced insulin resistance through up-regulation of the p85 regulatory subunit of PI3K.

GH stimulates lipolysis via activation of the hormonesensitive lipase, primarily in the visceral adipose tissue, which results in free fatty acid (FFA) flux from adipose tissue to circulation ${ }^{1)}$. Previous studies have shown that increased FFA in circulation can induce insulin resistance by inhibition of insulin receptor substrate-1 (IRS-1) activity and subsequent failure of PI3K activation in the skeletal muscle and liver ${ }^{1)}$. Meanwhile, increase in FFA uptake by hepatocytes result in promotion of hepatic lipid oxidation and accumulation of acetyl Coenzyme A (Acetyl-CoA). Acetyl-CoA stimulates two key enzymes for gluconeogenesis (pyruvate carboxylase and phosphoenolpyruvate carboxykinase) and an enzyme liberates glucose-6-phosphate as glucose from the liver and kidney into circulation (glucose-6-phosphatase), resulting in an increase of blood glucose levels".

In contrast to the $\mathrm{GH}$ effects on adipose tissue, $\mathrm{GH}$ promotes cellular uptake of FFA in skeletal muscle by increasing the activity of lipoprotein lipase ${ }^{10)}$. The re-esterification of triglycerides from FFA results in the accumulation of lipid intermediates such as diacylglycerol and ceramides in skeletal muscle ${ }^{11}$. Previous studies have revealed that diacylglycerol and ceramide impede insulin signaling pathways. Diacylglycerol activates protein kinase $\mathrm{C}$ theta, which inhibit IRS-1 through serine phosphorylation, and ceramide inhibits Akt/protein kinase B, an important mediator of the insulin signaling pathway ${ }^{11}$. As in the adipose tissue, up-regulation of the p 85 regulatory subunit in skeletal muscle by GH was involved in insulin resistance in mice with excess $\mathrm{GH}$ production ${ }^{12)}$.

The cross-talk between insulin and GH downstream of receptor activation in the skeletal muscle and adipose tissue provides another alternative potent mechanism mediating $\mathrm{GH}$ induced insulin resistance, which is supported by experiments both in vitro and in animal models. IGF-1 production and somatic growth by GH is mediated via the Janus kinase 2 (JAK2)/signal transducer and activator of transcription 5 (STAT5) signaling pathway. GH-induced STAT5 activation increases expression of suppressor of cytokine signaling (SOCS), which interferes with JAK2/STAT5 and consequently downregulates $\mathrm{GH}$ action ${ }^{13)}$. Crosstalk between $\mathrm{GH}$ and insulin receptors occurs at the level of SOCS proteins. Overexpression of SOCS proteins was reported to induce insulin resistance either via inhibition of insulin-induced IRS-1 phosphorylation or via degradation of IRS- $1^{14)}$. Despite numerous in vitro studies and animal models supporting this hypothesis, human studies have failed to demonstrate direct inhibitory effects of GH on insulin signaling pathways in skeletal muscle or fat ${ }^{15)}$.

Hyperinsulinism after GH administration or in excess GH conditions have been explained by beta-cell compensation for insulin resistance; however, a recent study found that GH directly promotes beta-cell proliferation and glucose-stimulated insulin secretion ${ }^{16)}$. In theory, persistently high FFA in chronic excess GH (e.g., acromegaly) may cause beta-cell apoptosis and a subsequent decrease in insulin secretion ${ }^{17}$, but in vivo evidence in unclear.

\section{Effects of IGF-1 on glucose metabolism}

Excess GH or GH administration in vivo are followed by an increase in circulating IGF-1 levels, therefore net effects of GH on glucose metabolism are complicated by IGF-1 effects. The receptors for IGF-1 and insulin are highly homologous in structure and biological function. Binding of the ligands results in autophosphorylation of the intracellular kinase domains and subsequent activation of downstream signaling cascades, which regulate gene transcription involved in substrate metabolism, cell growth and differentiation. IGF-1 and insulin strongly activate their respective receptors, but can also bind and weakly activate each other's receptors ${ }^{18)}$. IGF1 had caused a hypoglycemic effect in previous in vivo studies through stimulation of glucose uptake and gluconeogenesis, possibly either via activation of IGF-1 or via insulin receptors ${ }^{19)}$. For example, administration of recombinant human IGF1 to insulin receptor deficient mice induced insulin-mimetic effects, including both an increase in glucose uptake of skeletal muscle and a decrease in hepatic gluconeogenesis, through IGF-1 receptor activation. Consistent with this, IGF-1 infusion improved serum glucose levels in individuals with diabetes mellitus ${ }^{20)}$. 


\section{GH treatment and glucose metabolism in $\mathrm{GH}$ deficient adults}

The clinical presentations of GH-deficient adults are characterized by increased visceral adiposity, insulin resistance, dyslipidemia and hyperglycemia, which contributes to increased risk of cardiovascular morbidity and mortality ${ }^{2)}$. Because IGF-1 has anti-inflammatory properties and is important for glucose uptake from peripheral tissues, metabolic disturbances in GH-deficient adults can be explained by the IGF-1 deficit ${ }^{1)}$. A deprivation of $\mathrm{GH}$-induced lipolysis and subsequent increased visceral adiposity are also involved in increased circulating FFAs and insulin resistance in these patients ${ }^{2}$. Most of the metabolic disturbances, including visceral adiposity, sarcopenia, hypertension, and dyslipidemia were reported to be relieved after $\mathrm{GH}$ treatment ${ }^{1)}$. However, a number of studies suggested that there are possible negative impacts on glucose homeostasis such as impaired glucose tolerance as well as insulin sensitivity in patients with GH deficiency after GH administration. Notably, the interpretation of human studies regarding GH treatment

Table 1. Effects of recombinant human GH treatment on glucose metabolism in adults with GH deficiency

\begin{tabular}{|c|c|c|c|c|c|}
\hline Study & $\begin{array}{l}\text { Number of } \\
\text { GHD cases }\end{array}$ & Age (yr) & Daily GH dose & Duration of GHT & Findings \\
\hline \multicolumn{6}{|l|}{ High dose } \\
\hline Fowelin et al. ${ }^{35)}$ & 9 & $38-63$ & $0.023 \mathrm{mg} / \mathrm{kg}$ & $\begin{array}{l}6 \text { Weeks } \\
26 \text { Weeks }\end{array}$ & $\begin{array}{l}\uparrow \text { Fasting glucose, } \uparrow \text { insulin, } \downarrow \text { IS (EC) } \\
\leftrightarrow \text { Fasting glucose, } \leftrightarrow \text { insulin, } \downarrow \text { IS (EC) }\end{array}$ \\
\hline Chipman et al. ${ }^{36)}$ & $\mathrm{AO}(\mathrm{rhGH}=52, \mathrm{P}=46)$ & $43.5 \pm 9.8$ & $0.012 \mathrm{mg} / \mathrm{kg}$ & $\begin{array}{l}6 \text { Months } \\
18 \text { Months }\end{array}$ & $\begin{array}{l}\uparrow \text { Fasting glucose, } \leftrightarrow \text { insulin, } \leftrightarrow \mathrm{HbA}_{1 c} \\
\leftrightarrow \text { Fasting glucose, } \leftrightarrow \text { insulin, } \leftrightarrow \mathrm{HbA}_{1 c}\end{array}$ \\
\hline & $\mathrm{CO}(\mathrm{rhGH}=32, \mathrm{P}=35)$ & $28.4 \pm 7.2$ & $0.012 \mathrm{mg} / \mathrm{kg}$ & $\begin{array}{l}6 \text { Months } \\
18 \text { Months }\end{array}$ & $\begin{array}{l}\uparrow \text { Fasting glucose, } \uparrow \text { insulin, } \leftrightarrow \mathrm{HbA}_{1 c} \\
\leftrightarrow \text { Fasting glucose, } \leftrightarrow \text { insulin, } \leftrightarrow \mathrm{HbA}_{1 c}\end{array}$ \\
\hline Hwu et al. ${ }^{21)}$ & $\mathrm{rhGH}=7, \mathrm{P}=9$ & $20-44$ & $0.011 \mathrm{mg} / \mathrm{kg}$ & $\begin{array}{l}6 \text { Months } \\
12 \text { Months }\end{array}$ & $\begin{array}{l}\leftrightarrow \text { Fasting glucose, } \leftrightarrow I S(M I S T) \\
\leftrightarrow \text { Fasting glucose, } \downarrow \text { IS (MIST) }\end{array}$ \\
\hline Christopher et al. ${ }^{37)}$ & $\mathrm{rhGH}=7, \mathrm{P}=7$ & $43.7 \pm 4.1$ & $0.011 \mathrm{mg} / \mathrm{kg}$ & $\begin{array}{l}6 \text { Months } \\
24 \text { Months }\end{array}$ & $\begin{array}{l}\uparrow \text { Fasting glucose, } \leftrightarrow \text { insulin, } \leftrightarrow \mathrm{HbA}_{1 c} \\
\leftrightarrow \text { Fasting glucose, } \uparrow \text { insulin, } \downarrow \mathrm{IS}(\mathrm{EC})\end{array}$ \\
\hline Rosenfalck et al. ${ }^{22)}$ & 11 & $26-57$ & $0.016 \mathrm{mg} / \mathrm{kg}$ & 30 Months & $\uparrow A \cup C$ gluc, $\uparrow$ AUC insulin (OGTT), $\downarrow$ IS (FSIGT) \\
\hline Sesmilo et al. ${ }^{38)}$ & $\mathrm{rhGH}=20, P=20$ & $24-64$ & $0.01 \mathrm{mg} / \mathrm{kg}$ & $\begin{array}{l}6 \text { Months } \\
18 \text { Months }\end{array}$ & $\begin{array}{l}\uparrow \text { Fasting glucose, } \uparrow \text { insulin, } \leftrightarrow \mathrm{HbA}_{1 c} \\
\uparrow \text { Fasting glucose, } \leftrightarrow \text { insulin, } \leftrightarrow \mathrm{HbA}_{1 c}\end{array}$ \\
\hline Chrisoulidou et al. ${ }^{39)}$ & $\mathrm{rhGH}=12, \mathrm{C}=21$ & $52 \pm 10$ & $0.7 \mathrm{mg}$ & 7 Years & $\begin{array}{l}\leftrightarrow \text { Fating glucose, } \leftrightarrow \text { insulin, } \leftrightarrow \text { AUC gluc, } \\
\uparrow \text { AUC insulin (OGTT) }\end{array}$ \\
\hline Giavoli et al. ${ }^{40)}$ & 20 & $44 \pm 14$ & $0.01-0.024 \mathrm{mg} / \mathrm{kg}$ & $\begin{array}{l}1 \text { Year } \\
5 \text { Years }\end{array}$ & $\begin{array}{l}\uparrow \text { Fasting gluose, } \uparrow \text { HOMA-IR, } \downarrow \text { QUICKI } \\
\uparrow \text { Fasting gluose, } \leftrightarrow \text { HOMA-IR, } \leftrightarrow \text { QUICKI }\end{array}$ \\
\hline \multicolumn{6}{|l|}{ Low dose } \\
\hline al-Shoumer et al. ${ }^{41)}$ & 13 & $24-65$ & $0.008 \mathrm{mg} / \mathrm{kg}$ & $\begin{array}{l}1 \text { Year } \\
4 \text { Years }\end{array}$ & $\begin{array}{l}\uparrow \text { Fasting gluose, } \uparrow \text { AUC gluc, } \uparrow \text { AUC insulin (OGTT) } \\
\leftrightarrow \text { Fasting glucose, } \leftrightarrow \text { AUC gluc, } \leftrightarrow \text { AUC insulin (OGTT) }\end{array}$ \\
\hline Gibney et al. ${ }^{42)}$ & $\mathrm{rhGH}=10, \mathrm{P}=11$ & $21-51$ & $0.008 \mathrm{mg} / \mathrm{kg}$ & 10 Years & $\leftrightarrow$ Fasting glucose, $\leftrightarrow$ insulin, $\leftrightarrow$ c-peptide \\
\hline Svensson et al. ${ }^{43)}$ & 11 & $52 \pm 3.9$ & $0.61 \mathrm{mg}$ & 7 Years & $\leftrightarrow$ Fasting glucose, $\leftrightarrow$ insulin, $\leftrightarrow \mid S(E C)$ \\
\hline Bramnert et al. ${ }^{44)}$ & $\mathrm{rhGH}=10, P=9$ & $42 \pm 2.6$ & $0.009 \mathrm{mg} / \mathrm{kg}$ & $\begin{array}{l}1 \text { Week } \\
6 \text { Months }\end{array}$ & $\begin{array}{l}\uparrow \text { Fasting glucose, } \uparrow \text { insulin, } \downarrow \text { IS (EC) } \\
\uparrow \text { Fasting glucose, } \uparrow \text { insulin, } \downarrow \text { IS (EC) }\end{array}$ \\
\hline Yuen et al. ${ }^{25)}$ & $\begin{array}{l}8 \\
8\end{array}$ & $\begin{array}{l}32-59 \\
31-60\end{array}$ & $\begin{array}{l}0.1 \mathrm{mg} \\
0.5 \mathrm{mg}\end{array}$ & 12 Months & $\begin{array}{l}\downarrow \text { Fasting glucose, } \leftrightarrow \text { insulin, } \uparrow \text { HOMA-S } \\
\leftrightarrow \text { Fasting glucose, } \leftrightarrow \text { insulin, } \leftrightarrow \text { HOMA-S }\end{array}$ \\
\hline Roemmler et al. ${ }^{45)}$ & $\mathrm{rhGH}=22, \mathrm{C}=30$ & $27-82$ & $0.30 \mathrm{mg}$ & $\begin{array}{l}\text { 2-42 Years } \\
\text { (mean 11) }\end{array}$ & $\begin{array}{l}\downarrow \text { Fasting glucose, } \leftrightarrow \text { insulin, } \leftrightarrow H O M A-I R, \leftrightarrow H b A_{1 c} \\
\leftrightarrow \text { AUC gluc, } \leftrightarrow \text { AUC insulin, } \leftrightarrow \mathrm{S}(\mathrm{OGTT})\end{array}$ \\
\hline Woodmansee et al. ${ }^{23)}$ & $\begin{array}{c}\text { No DM } \\
(\text { rhGH=337, C=134) } \\
\text { DM (rhGH=64, C=35) }\end{array}$ & $\begin{array}{l}48.9 \pm 0.7 \\
56.0 \pm 1.7\end{array}$ & $0.36 \mathrm{mg}$ & $2.33 \pm 1.34$ Years & $\begin{array}{l}\leftrightarrow \mid \mathrm{FG}(>109 \mathrm{mg} / \mathrm{dL}), \leftrightarrow \mathrm{HbA}_{1 c} \\
\leftrightarrow \mid \mathrm{FG}(>109 \mathrm{mg} / \mathrm{dL}), \leftrightarrow \mathrm{HbA}_{1 c}\end{array}$ \\
\hline Elbornsson et al..$^{24)}$ & 156 & 22-74 & $0.40 \mathrm{mg}$ & 15 Years & $\begin{array}{l}\uparrow \text { Fasting glucose (year 1-year 10), } \\
\downarrow \mathrm{HbA}_{1 \mathrm{c}} \text { (year 7-year 15) }\end{array}$ \\
\hline Yuen and Dunger ${ }^{26)}$ & $\mathrm{rhGH}=8, \mathrm{C}=9$ & $46 \pm 3.7$ & $0.005 \mathrm{mg} / \mathrm{kg}$ & 3 Months & $\leftrightarrow$ Fasting glucose, $\leftrightarrow$ insulin, $\uparrow$ IS (EC) \\
\hline Weber et al. ${ }^{46)}$ & 245 & $49 \pm 14$ & $0.37 \mathrm{mg}$ & 4 Years & $\leftrightarrow$ Fasting glucose, $\leftrightarrow \mathrm{HbA}_{1 c}$ \\
\hline
\end{tabular}

Participant's age was presented in mean \pm standard deviation or range.

$\mathrm{GH}$, growth hormone; GHD, growth hormone deficiency; GHT, growth hormone treatment; IS, insulin sensitivity; EC, euglycemic clamp; $\mathrm{AO}$, adult onset; $\mathrm{HbA}_{1 c}$ glycosylated hemoglobin; $\mathrm{CO}$, childhood onset; rhGH, recombinant human growth hormone; MIST, modified insulin suppression test; HOMA-IR, homeostasis model assessment of insulin resistance; AUC gluc, the area under the curve for glucose; AUC insulin, the area under the curve for insulin; OGTT, oral glucose tolerance test; P, placebo; FSIGT, frequently-sampled intravenous glucose tolerance test; QUICKI, quantitative insulin check index; HOMA-S, homeostasis model assessment of insulin sensitivity. 
and associated changes of glucose metabolism is intricate, because dosage and duration of GH as well as age, body mass index (BMI), and family history of diabetes in study participants can influence the study results.

The original dosage of GH treatment used in GH deficient adults were body weight-adjusted high dosing derived from the dosage used in GH deficient children, however this practice has changed to individualized dosing with lower doses to avoid adverse events of overtreatment since early 2000s. Many of the early studies using high $\mathrm{GH}$ doses $(\geq 0.01 \mathrm{mg} / \mathrm{kg} /$ day) reported that fasting glucose and insulin levels increased after shortterm GH treatment for less than 6 months, but were usually restored to baseline levels after 1 or 2 years of GH treatment (Table 1). GH treatment in high doses was effective for the reduction of total and visceral fat mass ${ }^{21,22)}$. However, long-term GH replacement in high doses decreased insulin sensitivity and aggravated insulin resistance, which can be explained by the anti-insulin effects of GH. Despite increased insulin resistance, hemoglobin $\mathrm{A}_{1 \mathrm{c}}\left(\mathrm{HbA}_{\mathrm{lc}}\right)$ levels remained unchanged in both short-term and long-term treatment (Table 1).

Low-dose GH administration in GH-deficient adults has been reported to be effective in improving body composition, albeit to a lesser degree than high-dose $\mathrm{GH}^{23,24)}$. Most of the studies using low-dose GH treatment $(<0.01 \mathrm{mg} / \mathrm{kg} /$ day $)$ demonstrated no significant change or just a transient increase in fasting glucose levels (Table 1). Most of these studies reported unchanged insulin resistance and insulin sensitivity after longterm treatment with low-dose GH. Two studies conducted by the same investigators ${ }^{25,26)}$ showed an improvement of insulin sensitivity in GH-deficient patients with obesity after a shortterm treatment with a fixed low-dose GH $(0.1 \mathrm{mg} /$ day $)$. Most studies with low-dose GH treatment reported no significant changes in $\mathrm{HbA}_{1 \mathrm{c}}$ levels, although a few studies showed a mild decrease in $\mathrm{HbA}_{1 \mathrm{c}}$ within normal range in $\mathrm{GH}$ deficient adults ${ }^{24)}$. One study investigated the effect of $\mathrm{GH}$ on fasting glucose levels and $\mathrm{HbA}_{1 \mathrm{c}}$ in $\mathrm{GH}$-deficient patients with pre-existing diabetes mellitus, and it revealed a mild elevation of fasting glucose without statistical significance and no aggravation of $\mathrm{HbA}_{1 c}$ values $^{233}$.

Recent studies assessed the risk of development of diabetes mellitus after low-dose GH treatment (Table 2). Because GHdeficient adults are at increased risk of impaired glucose tolerance compared to the general population, it is sufficient to compare the incidence of diabetes in GH treated patients with that of untreated patients. Currently, only one study with relatively short duration (2.3 years) reported that there was no increased risk of diabetes mellitus in GH-deficient adults after $\mathrm{GH}$ treatment compared with untreated GHdeficient controls $^{27)}$. Other studies compared the incidence of diabetes between GH treated patients and the normal general population, and most of them revealed no significant increase in the incidence of diabetes after 2-10 years of GH treatment (Table 2). One study demonstrated 2-6 times higher incidence of diabetes mellitus than expected in the normal general population ${ }^{28)}$. It is noteworthy that increased age and $\mathrm{BMI}$, female sex, and duration of GH, but not the dose of GH, were associated with increased risk of diabetes mellitus in this study ${ }^{28)}$.

\section{GH treatment and glucose metabolism in GH deficient children and adolescents}

To date, relatively few studies have been conducted examining the change of glucose metabolism after GH treatment in the pediatric population. Most of these studies have demonstrated that increased insulin resistance, indicated by increased fasting insulin and homeostasis model assessment of insulin resistance levels, was observed during GH therapy in GH-deficient children and adolescents, but their fasting/postprandial glucose and $\mathrm{HbA}_{1 \mathrm{c}}$ levels remained withinin normal range (Table 3). A limited number of euglycemic clamp studies reported decreased insulin sensitivity in GH-deficient children after short-term GH treatment ${ }^{29,30)}$

Because increased insulin resistance and impaired insulin sensitivity are linked to the risk of glucose intolerance and diabetes mellitus, concerns have been raised regarding the possible development of diabetes mellitus during or after GH treatment in the long-term (Table 4). With the advent of National Cooperative Growth Study research ${ }^{31)}$, large pharmacoepidemiological studies have demonstrated that the incidences of type 2 diabetes mellitus increased more than 6 times in children under GH treatment compared with the general population, especially in patients with predisposing risk factors for diabetes, such as obesity, family history of diabetes, Turner syndrome, Prader-Will syndrome, or glucocorticoid treatment ${ }^{32,33}$. The development of diabetes mellitus was not

Table 2. Effects of recombinant human GH treatment on the development of DM in adults

\begin{tabular}{|c|c|c|c|c|c|}
\hline Study & Number of cases & Age (yr) & Daily GH dose & Duration of GHT & Findings \\
\hline Attanasio et al. ${ }^{47)}$ & 2,922 in US, 3,709 in Europe & $45.4 \pm 15$ & - & 4.1 Years & $\begin{array}{l}\leftrightarrow \text { DM prevalence ( } 11.3 \% \text { in US, } 5.7 \% \text { in Europe) } \\
\leftrightarrow \text { DM incidence } \\
\text { (n/1,000 patient-years: } 14.1 \text { in US, } 7.0 \text { in Europe) }\end{array}$ \\
\hline Luger et al. ${ }^{28)}$ & 5,143 KIMS cohort & $49 \pm 13$ & $0.36 \mathrm{mg}$ & 3.9 Years & $\uparrow D M$ incidence $26 / 1,000$ patient-years \\
\hline Hartman et al. ${ }^{27)}$ & $\mathrm{rhGH}=1,988$, control $=442$ & $46 \pm 15$ & $<0.012 \mathrm{mg} / \mathrm{kg}$ & 2.3 Years & $\leftrightarrow$ DM incidence \\
\hline Shimatsu et al. ${ }^{48)}$ & 209 in Japan & $18-64$ & $0.25 \mathrm{mg}$ & 2 Years & $\leftrightarrow \mathrm{DM}$ incidence \\
\hline
\end{tabular}

Participant's age was presented in mean \pm standard deviation or range.

GH, growth hormone; DM, diabetes mellitus; GHT, growth hormone treatment; KIMS, Pfizer International Metabolic Database; rhGH, recombinant human growth hormone. 
Table 3. Effects of recombinant human GH treatment on glucose metabolism in children and adolescents with GH deficiency

\begin{tabular}{|c|c|c|c|c|c|}
\hline Study & Number of cases & Age (yr) & Daily GH dose & Duration of GHT & Findings \\
\hline Saenger et al. ${ }^{49)}$ & $\mathrm{GHD}=70$ & - & $0.05 \mathrm{mg} / \mathrm{kg}$ & 5 Years & $\begin{array}{l}\leftrightarrow \text { Fasting/postprandial glucose, } \\
\uparrow \text { fasting/postprandial insulin, } \leftrightarrow \mathrm{HbA}_{10}\end{array}$ \\
\hline Heptulla et al. ${ }^{29)}$ & $\mathrm{GHD}=6, \mathrm{ISS}=2$ & $12 \pm 1$ & $0.05 \mathrm{mg} / \mathrm{kg}$ & 6 Months & $\leftrightarrow$ Fasting glucose, $\uparrow$ insulin, $\downarrow$ IS (HC) \\
\hline Radetti et al. ${ }^{50)}$ & $\mathrm{GHD}=128$, Healthy control $=40$ & $8.9 \pm 3.2$ & $0.04-0.05 \mathrm{mg} / \mathrm{kg}$ & 6 Years & $\downarrow$ QUICK, no cases with IGT, DM at 6 year \\
\hline Salerno et al. ${ }^{51)}$ & $\mathrm{GHD}=30$, Healthy control $=30$ & $9.3 \pm 0.5$ & $0.03 \mathrm{mg} / \mathrm{kg}$ & 2 Years & $\leftrightarrow$ Fasting glucose, $\uparrow$ insulin, $\uparrow$ HOMA-IR \\
\hline Metwalley et al. ${ }^{52)}$ & $\mathrm{GHD}=30$, Healthy control $=20$ & $4-10$ & $1 \mathrm{mg} / \mathrm{m} 2$ & 1 Year & $\uparrow$ Fasting glucose, $\uparrow$ insulin, $\uparrow$ HOMA-IR \\
\hline Meazza et al. ${ }^{53)}$ & $\mathrm{GHD}=16$, Healthy control $=20$ & $3.4-14.7$ & $0.025 \mathrm{mg} / \mathrm{kg}$ & 1 Year & $\uparrow$ Fasting glucose, $\uparrow$ insulin \\
\hline Ramistella et al. ${ }^{54)}$ & $\mathrm{GHD}=32$, Healthy control $=33$ & $8.9 \pm 3.6$ & $0.03 \mathrm{mg} / \mathrm{kg}$ & 2 Years & $\leftrightarrow$ Fasting glucose, $\uparrow$ insulin, $\uparrow$ HOMA-IR \\
\hline (iresi et al. ${ }^{30)}$ & $\mathrm{GHD}=73$, Healthy control $=50$ & $10.3 \pm 2.8$ & $0.025-0.033 \mathrm{mg} / \mathrm{kg}$ & 1 Year & $\begin{aligned} \leftrightarrow & \text { Fasting glucose, } \leftrightarrow \text { insulin, } \\
& \uparrow \mathrm{HOMA}-\mathrm{IR}, \downarrow \text { QUICKI, } \leftrightarrow \text { AUC gluc, } \\
& \downarrow \text { AUC insulin (OGTT), } \downarrow \text { IS (HC) }\end{aligned}$ \\
\hline
\end{tabular}

Participant's age was presented in meantstandard deviation or range.

$\mathrm{GH}$, growth hormone; GHT, growth hormone treatment; GHD, growth hormone deficiency; $\mathrm{HbA}_{1,}$ glycosylated hemoglobin; IS, insulin sensitivity; HC, hyperglycemic clamp; QUICKI, quantitative insulin check index; IGT, impaired glucose tolerance; DM, diabetes mellitus; HOMA-IR, homeostasis model assessment of insulin resistance; AUC gluc, the area under the curve for glucose; AUC insulin, the area under the curve for insulin; OGTT, oral glucose tolerance test.

Table 4. Effects of recombinant human GH treatment on the development of DM in children and adolescents

\begin{tabular}{|c|c|c|c|c|c|}
\hline Study & Number of cases & Age (yr) & Daily GH dose & Duration of GHT & Findings \\
\hline Blethen et al. ${ }^{311}$ & $>19,000$ NCGS cohort & $\begin{array}{c}7.2-12.9 \\
\text { (at enrollment) }\end{array}$ & - & - & $\begin{array}{l}\uparrow \text { DM incidence in subjects with identifiable } \\
\text { risk factors }\end{array}$ \\
\hline (utfield et al. ${ }^{32)}$ & 23,333 KIGS cohort & $10.3(7.2-12.7)$ & $\begin{array}{l}0.03 \mathrm{mg} / \mathrm{kg} \\
(0.02-0.04)\end{array}$ & 2.9 Years & $\begin{array}{l}\uparrow T 2 D M \text { incidence in subjects with identifiable } \\
\text { risk factors, } \leftrightarrow \text { T1DM incidence }\end{array}$ \\
\hline Child et al. ${ }^{33)}$ & 11,686 GeNeSIS cohort & $10.2(6.5-12.7)$ & $\begin{array}{l}0.04 \mathrm{mg} / \mathrm{kg} \\
(0.03-0.05)\end{array}$ & 2.5 Years & $\begin{array}{l}\uparrow T 2 D M \text { incidence in subjects with identifiable } \\
\text { risk factors, } \leftrightarrow \text { T1DM incidence }\end{array}$ \\
\hline Poidvin et al. ${ }^{34)}$ & $\begin{array}{l}\text { 5,100 French SAGhE cohort } \\
\text { (iGHD, ISS, SGA) }\end{array}$ & $20-44$ & $0.03 \pm 0.01 \mathrm{mg} / \mathrm{kg}$ & 4 Years & $\leftrightarrow$ DM prevalence \\
\hline
\end{tabular}

Participant's age was presented in mean \pm standard deviation, median (interquartile range), or range.

GH, growth hormone; DM, diabetes mellitus; GHT, growth hormone treatment; NCGS, National Cooperative Growth Study; KIGS, Pharmacia and Upjohn International Growth Study; T1DM, type 1 diabetes mellitus; T2DM, type 2 diabetes mellitus; GeNeSIS, GH-treated patients in the Genetics and Neuroendocrinology of Short Stature International Study; SAGhE, Safety and Appropriateness of Growth Hormone Treatments in Europe; iGHD, isolated growth hormone deficiency; ISS, idiopathic short stature; SGA, small-for-gestational age.

associated with the dose or duration of GH treatment, and the incidence of type 1 diabetes mellitus during GH treatment was comparable with that of the general population in all three studies ${ }^{31-33)}$. In comparison, a recent French population-based study reported that the prevalence of diabetes mellitus in $\mathrm{GH}$ treated children was similar to the general population when patients reached early adulthood ${ }^{34)}$. Of note, this study included patients with isolated GH deficiency, idiopathic short stature, or short children born small-for-gestational age, excluding patients with high risk of mortality and morbidity, such as patients with cancer, chronic renal failure, multiple pituitary hormone deficiency, Turner syndrome or Prader-Willi syndrome ${ }^{34)}$.

\section{Summary}

GH therapy antagonizes insulin's action on peripheral tissues, such as the skeletal muscle, liver, and adipose tissue, thereby increases glucose production from the skeletal muscle and liver and decreases glucose uptake from adipose tissue. Insulin production is increased to compensate the increased circulating glucose after $\mathrm{GH}$ administration. $\mathrm{GH}$-induced lipolysis in the visceral adipose tissue and subsequent increased circulating FFA also interferes with insulin signaling pathways, and chronic exposure to high FFA may exert direct toxicity in beta-cells. Meanwhile, IGF-1 has insulin-mimetic actions in the skeletal muscle and liver, and increased circulating IGF-1 after $\mathrm{GH}$ administration may have beneficial effects on glucose homeostasis and insulin resistance.

A number of human studies have suggested that $\mathrm{GH}$ administration in GH deficient adults may reduce visceral adiposity and improve cardio-metabolic disturbance. However, some studies raised concerns over increased insulin resistance and impaired fasting glucose during GH treatment, especially in patients with obesity and elderly patients. Studies in children and adolescents also suggested that GH administration may induce insulin resistance in short-term treatment, but its long-term consequences have not been fully determined yet. International cohort studies indicate that GH therapy may increase the incidence of type 2 diabetes mellitus in children and adolescents with predisposing risk factors, therefore it is prudent to monitor possible negative consequences on glucose metabolism during and after GH administration. Large-scale longitudinal cohort studies are required to examine the long-term influence of $\mathrm{GH}$ 
therapy on cardiovascular outcomes in GH-deficient children with or without continuation of GH after cessation of skeletal growth.

\section{Conflict of interest}

No potential conflict of interest relevant to this article was reported.

\section{References}

1. Vijayakumar A, Yakar S, Leroith D. The intricate role of growth hormone in metabolism. Front Endocrinol (Lausanne) 2011;2:32.

2. Moller N, Jorgensen JO. Effects of growth hormone on glucose, lipid, and protein metabolism in human subjects. Endocr Rev 2009;30:152-77.

3. Schwarz JM, Mulligan K, Lee J, Lo JC, Wen M, Noor MA, et al. Effects of recombinant human growth hormone on hepatic lipid and carbohydrate metabolism in HIV-infected patients with fat accumulation. J Clin Endocrinol Metab 2002;87:942.

4. Kim YD, Li T, Ahn SW, Kim DK, Lee JM, Hwang SL, et al. Orphan nuclear receptor small heterodimer partner negatively regulates growth hormone-mediated induction of hepatic gluconeogenesis through inhibition of signal transducer and activator of transcription 5 (STAT5) transactivation. J Biol Chem 2012;287:37098-108.

5. Hoybye C, Chandramouli V, Efendic S, Hulting AL, Landau $\mathrm{BR}$, Schumann WC, et al. Contribution of gluconeogenesis and glycogenolysis to hepatic glucose production in acromegaly before and after pituitary microsurgery. Horm Metab Res 2008;40:498-501.

6. Cho Y, Ariga M, Uchijima Y, Kimura K, Rho JY, Furuhata Y, et al. The novel roles of liver for compensation of insulin resistance in human growth hormone transgenic rats. Endocrinology 2006; 147:5374-84.

7. Kilgour E, Baldwin SA, Flint DJ. Divergent regulation of rat adipocyte GLUT1 and GLUT4 glucose transporters by GH. J Endocrinol 1995;145:27-33.

8. del Rincon JP, Iida K, Gaylinn BD, McCurdy CE, Leitner JW, Barbour LA, et al. Growth hormone regulation of p85alpha expression and phosphoinositide 3-kinase activity in adipose tissue: mechanism for growth hormone-mediated insulin resistance. Diabetes 2007;56:1638-46.

9. Kovacs P, Stumvoll M. Fatty acids and insulin resistance in muscle and liver. Best Pract Res Clin Endocrinol Metab 2005;19:625-35.

10. LeRoith D, Yakar S. Mechanisms of disease: metabolic effects of growth hormone and insulin-like growth factor 1 . Nat Clin Pract Endocrinol Metab 2007;3:302-10.

11. Coen PM, Goodpaster BH. Role of intramyocelluar lipids in human health. Trends Endocrinol Metab 2012;23:391-8.

12. Barbour LA, Shao J, Qiao L, Leitner W, Anderson M, Friedman JE, et al. Human placental growth hormone increases expression of the p85 regulatory unit of phosphatidylinositol 3-kinase and triggers severe insulin resistance in skeletal muscle. Endocrinology 2004;145:1144-50.

13. Ram PA, Waxman DJ. SOCS/CIS protein inhibition of growth hormone-stimulated STAT5 signaling by multiple mechanisms. J Biol Chem 1999;274:35553-61.

14. Rui L, Yuan M, Frantz D, Shoelson S, White MF. SOCS1 and SOCS-3 block insulin signaling by ubiquitinmediated degradation of IRS1 and IRS2. J Biol Chem 2002;277:42394-8.

15. Krusenstjerna-Hafstrom T, Madsen M, Vendelbo MH, Pedersen SB, Christiansen JS, Moller N, et al. Insulin and GH signaling in human skeletal muscle in vivo following exogenous GH exposure: impact of an oral glucose load. PLoS One 2011;6:e19392.

16. Wu Y, Liu C, Sun H, Vijayakumar A, Giglou PR, Qiao R, et al. Growth hormone receptor regulates beta cell hyperplasia and glucose-stimulated insulin secretion in obese mice. J Clin Invest 2011;121:2422-6.

17. Unger RH, Zhou YT. Lipotoxicity of beta-cells in obesity and in other causes of fatty acid spillover. Diabetes 2001;50 Suppl 1:S118-21.

18. Boucher J, Tseng YH, Kahn CR. Insulin and insulin-like growth factor-1 receptors act as ligand-specific amplitude modulators of a common pathway regulating gene transcription. J Biol Chem 2010;285:17235-45.

19. Mauras N, Haymond MW. Are the metabolic effects of GH and IGF-I separable? Growth Horm IGF Res 2005;15:1927.

20. Moses AC, Young SC, Morrow LA, O'Brien M, Clemmons DR. Recombinant human insulin-like growth factor I increases insulin sensitivity and improves glycemic control in type II diabetes. Diabetes 1996;45:91-100.

21. Hwu CM, Kwok CF, Lai TY, Shih KC, Lee TS, Hsiao LC, et al. Growth hormone $(\mathrm{GH})$ replacement reduces total body fat and normalizes insulin sensitivity in GH-deficient adults: a report of one-year clinical experience. J Clin Endocrinol Metab 1997;82:3285-92.

22. Rosenfalck AM, Maghsoudi S, Fisker S, Jorgensen JO, Christiansen JS, Hilsted J, et al. The effect of 30 months of low-dose replacement therapy with recombinant human growth hormone (rhGH) on insulin and C-peptide kinetics, insulin secretion, insulin sensitivity, glucose effectiveness, and body composition in GH-deficient adults. J Clin Endocrinol Metab 2000;85:4173-81.

23. Woodmansee WW, Hartman ML, Lamberts SW, Zagar AJ, Clemmons DR, International Hypo CCSAB. Occurrence of impaired fasting glucose in $\mathrm{GH}$-deficient adults receiving GH replacement compared with untreated subjects. Clin Endocrinol (Oxf) 2010;72:59-69.

24. Elbornsson M, Gotherstrom G, Bosaeus I, Bengtsson BA, Johannsson G, Svensson J. Fifteen years of GH replacement improves body composition and cardiovascular risk factors. Eur J Endocrinol 2013;168:745-53.

25. Yuen KC, Dunger DB. Persisting effects on fasting glucose levels and insulin sensitivity after 6 months 
of discontinuation of a very low-dose GH therapy in adults with severe GH deficiency. Clin Endocrinol (Oxf) 2006;64:549-55.

26. Yuen KC, Roberts CT Jr, Frystyk J, Rooney WD, Pollaro JR, Klopfenstein BJ, et al. Short-term, low-dose GH therapy improves insulin sensitivity without modifying cortisol metabolism and ectopic fat accumulation in adults with GH deficiency. J Clin Endocrinol Metab 2014;99:E1862-9.

27. Hartman ML, Xu R, Crowe BJ, Robison LL, Erfurth EM, Kleinberg DL, et al. Prospective safety surveillance of GHdeficient adults: comparison of GH-treated vs untreated patients. J Clin Endocrinol Metab 2013;98:980-8.

28. Luger A, Mattsson AF, Koltowska-Haggstrom M, Thunander M, Goth M, Verhelst J, et al. Incidence of diabetes mellitus and evolution of glucose parameters in growth hormone-deficient subjects during growth hormone replacement therapy: a long-term observational study. Diabetes Care 2012;35:57-62.

29. Heptulla RA, Boulware SD, Caprio S, Silver D, Sherwin RS, Tamborlane WV. Decreased insulin sensitivity and compensatory hyperinsulinemia after hormone treatment in children with short stature. J Clin Endocrinol Metab 1997;82:3234-8.

30. Ciresi A, Ciccio F, Amato MC, Giordano C. Revaluation of the clinical and metabolic behavior of children with isolated growth hormone deficiency during $\mathrm{GH}$ treatment according to newly proposed note 39 of the Italian Medicines Agency (AIFA). J Endocrinol Invest 2015;38:1301-7.

31. Blethen SL, Allen DB, Graves D, August G, Moshang T, Rosenfeld R. Safety of recombinant deoxyribonucleic acid-derived growth hormone: The National Cooperative Growth Study experience. J Clin Endocrinol Metab 1996;81:1704-10.

32. Cutfield WS, Wilton P, Bennmarker H, Albertsson-Wikland $\mathrm{K}$, Chatelain P, Ranke MB, et al. Incidence of diabetes mellitus and impaired glucose tolerance in children and adolescents receiving growth-hormone treatment. Lancet 2000;355:610-3.

33. Child CJ, Zimmermann AG, Scott RS, Cutler GB Jr, Battelino T, Blum WF, et al. Prevalence and incidence of diabetes mellitus in GH-treated children and adolescents: analysis from the GeNeSIS observational research program. J Clin Endocrinol Metab 2011;96:E1025-34.

34. Poidvin A, Weill A, Ecosse E, Coste J, Carel JC. Risk of diabetes treated in early adulthood after growth hormone treatment of short stature in childhood. J Clin Endocrinol Metab 2017;102:1291-8.

35. Fowelin J, Attvall S, Lager I, Bengtsson BA. Effects of treatment with recombinant human growth hormone on insulin sensitivity and glucose metabolism in adults with growth hormone deficiency. Metabolism 1993;42:1443-7.

36. Chipman JJ, Attanasio AF, Birkett MA, Bates PC, Webb S, Lamberts SW. The safety profile of GH replacement therapy in adults. Clin Endocrinol (Oxf) 1997;46:473-81.

37. Christopher M, Hew FL, Oakley M, Rantzau C, Alford
F. Defects of insulin action and skeletal muscle glucose metabolism in growth hormone-deficient adults persist after 24 months of recombinant human growth hormone therapy. J Clin Endocrinol Metab 1998;83:1668-81.

38. Sesmilo G, Biller BM, Llevadot J, Hayden D, Hanson G, Rifai N, et al. Effects of growth hormone administration on inflammatory and other cardiovascular risk markers in men with growth hormone deficiency. A randomized, controlled clinical trial. Ann Intern Med 2000;133:111-22.

39. Chrisoulidou A, Beshyah SA, Rutherford O, Spinks TJ, Mayet J, Kyd P, et al. Effects of 7 years of growth hormone replacement therapy in hypopituitary adults. J Clin Endocrinol Metab 2000;85:3762-9.

40. Giavoli C, Porretti S, Ronchi CL, Cappiello V, Ferrante E, Orsi E, et al. Long-term monitoring of insulin sensitivity in growth hormone-deficient adults on substitutive recombinant human growth hormone therapy. Metabolism 2004:53:740-3.

41. al-Shoumer KA, Gray R, Anyaoku V, Hughes C, Beshyah $\mathrm{S}$, Richmond W, et al. Effects of four years' treatment with biosynthetic human growth hormone $(\mathrm{GH})$ on glucose homeostasis, insulin secretion and lipid metabolism in GH-deficient adults. Clin Endocrinol (Oxf) 1998;48:795802.

42. Gibney J, Wallace JD, Spinks T, Schnorr L, Ranicar A, Cuneo $\mathrm{RC}$, et al. The effects of 10 years of recombinant human growth hormone $(\mathrm{GH})$ in adult $\mathrm{GH}$-deficient patients. J Clin Endocrinol Metab 1999;84:2596-602.

43. Svensson J, Fowelin J, Landin K, Bengtsson BA, Johansson JO. Effects of seven years of GH-replacement therapy on insulin sensitivity in GH-deficient adults. J Clin Endocrinol Metab 2002;87:2121-7.

44. Bramnert M, Segerlantz M, Laurila E, Daugaard JR, Manhem P, Groop L. Growth hormone replacement therapy induces insulin resistance by activating the glucosefatty acid cycle. J Clin Endocrinol Metab 2003;88:1455-63.

45. Roemmler J, Kuenkler M, Schneider HJ, Dieterle C, Schopohl J. Comparison of glucose and lipid metabolism and bone mineralization in patients with growth hormone deficiency with and without long-term growth hormone replacement. Metabolism 2010;59:350-8.

46. Weber MM, Biller BM, Pedersen BT, Pournara E, Christiansen JS, Hoybye C. The effect of growth hormone (GH) replacement on blood glucose homeostasis in adult nondiabetic patients with GH deficiency: real-life data from the NordiNet(R) International Outcome Study. Clin Endocrinol (Oxf) 2017;86:192-8.

47. Attanasio AF, Jung H, Mo D, Chanson P, Bouillon R, Ho $\mathrm{KK}$, et al. Prevalence and incidence of diabetes mellitus in adult patients on growth hormone replacement for growth hormone deficiency: a surveillance database analysis. J Clin Endocrinol Metab 2011;96:2255-61.

48. Shimatsu A, Tai S, Imori M, Ihara K, Taketsuna M, Funai J, et al. Efficacy and safety of growth hormone replacement therapy in Japanese adults with growth hormone deficiency: a post-marketing observational study. Endocr J 
2013;60:1131-44.

49. Saenger P, Attie KM, DiMartino-Nardi J, Fine RN. Carbohydrate metabolism in children receiving growth hormone for 5 years. Chronic renal insufficiency compared with growth hormone deficiency, Turner syndrome, and idiopathic short stature. Genentech Collaborative Group. Pediatr Nephrol 1996;10:261-3.

50. Radetti G, Pasquino B, Gottardi E, Contadin IB, Rigon F, Aimaretti G. Insulin sensitivity in growth hormonedeficient children: influence of replacement treatment. Clin Endocrinol (Oxf) 2004;61:473-7.

51. Salerno M, Esposito V, Farina V, Radetti G, Umbaldo A, Capalbo D, et al. Improvement of cardiac performance and cardiovascular risk factors in children with GH deficiency after two years of GH replacement therapy: an observational, open, prospective, case-control study. J Clin Endocrinol Metab 2006;91:1288-95.

52. Metwalley KA, Farghaly HS, Abd El-Hafeez HA. Evaluation of left ventricular mass and function, lipid profile, and insulin resistance in Egyptian children with growth hormone deficiency: A single-center prospective casecontrol study. Indian J Endocrinol Metab 2013;17:876-82.

53. Meazza C, Elsedfy HH, Pagani S, Bozzola E, El Kholy M, Bozzola M. Metabolic parameters and adipokine profile in growth hormone deficient (GHD) children before and after 12-month GH treatment. Horm Metab Res 2014;46:21923.

54. Ramistella V, Wasniewska M, Arasi S, Catena M, Velletri $\mathrm{MR}$, Corica D, et al. Cross-sectional and prospective study of the effects of GH therapy on metabolic panel in children with GH deficiency. Pediatr Med Chir 2014;36:104. 